\title{
Apoptosis and surfactant protein-C expression inhibition induced by lipopolysaccharide in AEC II cell may associate with NF-kB pathway
}

\author{
Jinle Lin ${ }^{1, *}$, Jun Tian ${ }^{3,4, *}$, Li Wang ${ }^{1}$, Weigang $\mathbf{W u}^{2}$, Huaying $\mathrm{Li}^{2}$, Xueyan Wang ${ }^{3}$, \\ Xiaobin Zeng ${ }^{2,3}$ and Wenwu Zhang ${ }^{1}$ \\ ${ }^{1}$ Department of Emergency and Critical Care Medicine, Baoan Hospital, Nanfang Medical University, \\ Shenzhen 518101, Guangdong Province, China \\ ${ }^{2}$ Central Lab of Longhua Branch, Shenzhen People's Hospital, 2nd Clinical Medical College of Jinan University, \\ Shenzhen 518120, Guangdong Province, China \\ ${ }^{3}$ Key Lab for New Drug Research of TCM and Shenzhen Branch, State R\&D Centre for Viro-Biotech, \\ Research Institute of Tsinghua University in Shenzhen, Shenzhen 518057, Guangdong Province, China \\ ${ }^{4}$ College of Life Science, Jiangsu Normal University, Xuzhou 221116, Jiangsu Province, China
}

(Received August 10, 2016; Accepted October 31, 2016)

\begin{abstract}
Lipopolysaccharide (LPS), a Gram-negative bacterial outer membrane component, is one of the major causes of septic shock. Herein we investigate LPS-induced apoptosis of rat alveolar epithelial type II cells (AEC II) and the effects of LPS on surfactant protein-C (SP-C) expression in AEC II, along with the possible molecular mechanisms. LPS exposure impaired cell viability and increased apoptosis of AEC II significantly in concentration-dependent manner embodied in increased caspase-3 expression and the activity of caspase-3. Simultaneously, our results also indicated that LPS inhibited surfactant protein-C (SP-C) expression in AEC II. Mechanistic studies revealed that LPS treatment significantly

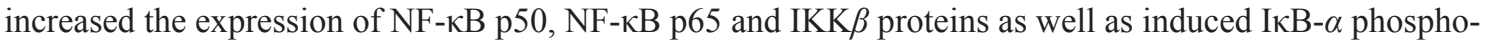
rylation. Moreover, pretreatment with IKK inhibitor IKK-16 or NF-kB inhibitor PDTC ameliorated LPScaused alterations in cleaved caspase- 3 expression, the activity of caspase- 3 and SP-C expression. Taken together, these results demonstrate that LPS can induce apoptosis of AEC II and decrease SP-C expression partly through activating the NF-kB pathway.
\end{abstract}

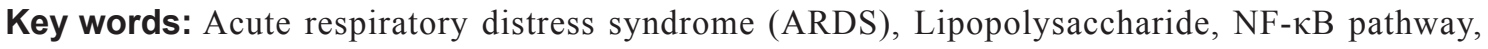
Apoptosis, Surfactant Protein-C

\section{INTRODUCTION}

Gram-negative septicemia, a complication from acute pulmonary infection, can lead to organ dysfunction or hypoperfusion abnormalities (Cazzola et al., 2004). Lipopolysaccharide (LPS), a Gram-negative bacterial outer membrane component, has been reported as one of the major causes of septic shock (Raetz et al., 1991). Accumulating evidence indicates a consistent association between sepsis-associated acute respiratory distress syndrome (ARDS) and abnormal apoptosis of pulmonary alveolar type II epithelial cells (Gill et al., 2015). In this regard, many current studies have been conduct- ed to investigate whether modulating apoptosis could be a therapeutic target in sepsis-induced ARDS management. Recent findings indicated that therapies in attenuating alveolar type II epithelial cell apoptosis may have positive impacts on pathophysiological regulation of septic shock and acute lung injury, as well as the clinical course and outcome of patients with ARDS (Chuang et al., 2011).

Furthermore, LPS also induces acute pulmonary inflammation, causing rapid changes in the composition of the surfactant pool in human lung (Rooney, 2001). Pulmonary alveolar type II epithelial cells, located in the corners of the alveoli, highly specialize functions for synthesizing, secreting and reutilizing surfactants (Rooney,

Correspondence: Xiaobin Zeng (E-mail: 214210597@qq.com)

Wenwu Zhang (E-mail: eccm_bah@foxmail.com)

*These authors equally contributed to this work. 
2001). The critical function of pulmonary surfactants is to reduce surface tension at the alveolar air-liquid interface, thereby preventing alveolar collapse upon expiration and allowing for normal breathing (Clements and King, 1976). The pulmonary surfactant proteins (SPs) are secreted by alveolar type II cells, which reduce the surface tension of the alveoli and allow expansion of the lung during inspiration (Nkadi et al., 2009). There are four surfactant specific proteins including SP A-D. Among them, SP-A and SP-D participate in host defense in the lung, whereas SP-B and SP-C contribute to the surface tension-lowering activity (Avery, 2000). It has been confirmed that SP-B and SP-C protein deficiencies are associated with the pathogenesis of neonatal respiratory distress syndrome (RDS) (Yin et al., 2012; Danlois et al., 2000). SP-C, a small lipopeptide of $4.5 \mathrm{kDa}$ with 35 residues, exclusively produced in lungs by the AEC II cells, is believed to promote and stabilize membrane-interface contacts and to facilitate lipid exchange between lipid layers (Glasser et al., 2001; Lukovic et al., 2012). In contrast to SP-B, $\mathrm{SP}-\mathrm{C}$ is not as absolutely essential for lung ventilation and survival. However, SP-C deficient mice ultimately develop chronic respiratory failure (Glasser et al., 2008; Lawson et al., 2005). SP-C is lipid membrane-associated and thus probably performs its surface activity in a concerted manner. And it improves surfactant activity in particular interfacial adsorption, film stability and its respreading abilities (Cruz et al., 2000; Serrano and PerezGil, 2006; Wang et al., 1996), and it has been shown that these roles are particularly relevant at extensive lung expansion and relaxation during periods of high ventilatory demands (Almlén et al., 2008).

Therefore, this study was designed to evaluate the effects of LPS on its induced apoptosis and SP-C expression inhibiting activity and its possible mechanisms using the primary cultured rat AEC II cells as the experimental model.

\section{MATERIALS AND METHODS}

\section{Rat alveolar epithelial type II cell isolation and cell culture}

AECII cells were isolated from male Sprague-Dawley rats (150-200 g) (Guangdong Medical Laboratory Animal Center, Foshan, China) as described elsewhere (Hu et al., 2012). Rats were anesthetized with chloral hydrate and injected with heparin to prevent the formation of thrombi in the lung. Lungs were surgically removed and lavaged several times to remove most alveolar leukocytes. The lungs were perfused with phosphate buffer saline (PBS) for 5 times at $37^{\circ} \mathrm{C}$. The lungs were digested by instilling $10 \mathrm{~mL}$ elastase $\left(3 \mathrm{U} / \mathrm{mL}\right.$ in PBS) at $37^{\circ} \mathrm{C}$ and incubating for $15 \mathrm{~min}$. The above process was repeated twice. The cell suspension was mixed with $100 \mathrm{mg} / \mathrm{mL}$ DNAse I (Thermofisher Scientific, San Jose, CA, USA), incubated for $5 \mathrm{~min}$ at $37^{\circ} \mathrm{C}$ with gentle rotation to minimize cell clumping. The elastase reaction was stopped with fetal bovine serum (FBS) (Hyclone, Logan, Australia). The cells were incubated in two rat IgG-coated polystyrene bacteriological $100 \mathrm{~mm}$ petridishes $(1.5 \mathrm{mg}$ rat $\mathrm{IgG} / \mathrm{dish}$ ) sequentially at $37^{\circ} \mathrm{C}, 1 \mathrm{hr}$ each. The unattached cells were centrifuged at $250 \mathrm{~g}$ for $5 \mathrm{~min}$ and resuspended with $10 \mathrm{~mL}$ Dulbecco's Modified Eagle Media: Nutrient Mixture F-12 (DMEM/F12) (Gibco Brl/ Invitrogen Co., Carlsbad, CA, USA) containing 10\% FBS and $1 \%$ antibiotic $(100 \mathrm{U} / \mathrm{mL}$ penicillin and $100 \mu \mathrm{g} / \mathrm{mL}$ streptomycin) (Gibco Brl/Invitrogen Co.) at a concentration of $10^{6}$ cells $/ \mathrm{mL}$. To remove the remaining macrophages, the cells were incubated with rat $\mathrm{IgG}$ $(40 \mathrm{mg} / \mathrm{mL})$ at room temperature for $15 \mathrm{~min}$ with gentle rotation. Non-adherent cells were centrifuged and the cell pellet was resuspended in DMEM/F12 medium with $10 \% \mathrm{FBS}$ and $1 \%$ antibiotic $(100 \mathrm{U} / \mathrm{mL}$ penicillin and $100 \mu \mathrm{g} / \mathrm{mL}$ streptomycin). Cells were then cultured in DMEM/F12 supplemented with 10\% FBS and 1\% antibiotic (100 U/mL penicillin and $100 \mu \mathrm{g} / \mathrm{mL}$ streptomycin) at $37^{\circ} \mathrm{C}$ in a humid atmosphere containing $5 \% \mathrm{CO}_{2}$. The medium was changed every 3 days to remove the non-adherent cells.

\section{Cell viablility assays by Methylthiazolyldiphenyl- tetrazolium bromide (MTT)}

Cell viability was measured by the MTT assay. Briefly, the cells were plated in a 96-well plate $\left(4 \times 10^{3}\right.$ cells/ well). After $24 \mathrm{hr}$, the cells were treated with DMSO or different concentrations of LPS (Guangzhou Hewei Chemical Co., LTD, Guangdong, China), IKK-16 as a selective inhibitor of I $\mathrm{KB}$ kinase, which is more sensitive to IKK $\beta$ than IKK $\alpha$ (Selleck Chemicals, Shanghai, China) and pyrrolidine dithiocarbamate (PDTC), a potent inhibitor of nuclear factor kappa B (NF-kappa B) activation (Selleck Chemicals). After different time points of treatment, $100 \mu \mathrm{L}$ of $5 \mathrm{mg} / \mathrm{mL}$ MTT (Sigma-Aldrich, St. Louis, MO, USA) was added to each well for $4 \mathrm{hr}$, the medium was replaced with $200 \mu \mathrm{L}$ of Dimethyl Sulphoxide (DMSO), and the cells were incubated at room temperature in the dark for $6 \mathrm{hr}$. The optical density (OD) value was measured using a spectrophotometric microtiter plate reader at $570 \mathrm{~nm}$. The effect was expressed as percentage relative to the controls. 
Apoptosis and surfactant protein-C expression inhibition induced by lipopolysaccharide

\section{Cell apoptosis analysis by Annexin V-Fluoresceinisothiocyanate/Propidium lodide (Annexin V-FITC/PI) staining}

Apoptotic cells were detected using flow cytometry with Annexin V-FITC/PI dual staining according to the manufacturer's instruction of Invitrogen V13241 Dead Cell Apoptosis Kit (Invitrogen). After different concentrations of LPS, IKK-16 and PDTC treatment, the cells were harvested by trypsinization, rinsed twice with PBS, and suspended in $500 \mu \mathrm{L}$ of binding buffer. The suspended cells were incubated at $4^{\circ} \mathrm{C}$ with $5 \mu \mathrm{L}$ Annexin V-FITC solution for $15 \mathrm{~min}$, and incubated for another $5 \mathrm{~min}$ at $4^{\circ} \mathrm{C}$ after adding $10 \mu \mathrm{L}$ of PI solution. Flow cytometric analysis of apoptotic cells was performed with a flow cytometer (Beckman-Coulter, Inc., Brea, IN, USA). The flow cytometer was used to detect the emitted green fluorescence of Annexin V (FL1) and red fluorescence of PI (FL2) and for each sample 10,000 events were recorded. The amount of early apoptosis, late apoptosis, and necrosis was determined as the percentage of $\mathrm{AnnexinV}^{+} /$ $\mathrm{PI}$, AnnexinV $\mathrm{V}^{+} / \mathrm{PI}^{+}$, and AnnexinV-/PI+ cells, respectively.

\section{Cell apoptosis analysis by 4',6-diamidino-2- phenylindole (DAPI) staining}

After $24 \mathrm{hr}$ of treatment with different concentrations of LPS, IKK-16 and PDTC, cells were fixed with pre-chilled methanol for $2 \mathrm{~min}$, and then stained with $5 \mathrm{mg} / \mathrm{mL}$ of DAPI (Beyotime Institute of Biotechnology, Jiangsu, China) for $10 \mathrm{~min}$. Nuclei were examined and photographed using fluorescence microscopy.

\section{Caspase- 3 activity assay}

Cells were treated with various concentrations of LPS and then harvested and lysed in cell lysis buffer $[20 \mathrm{mM}$ Tris- $\mathrm{HCl}(\mathrm{pH} 7.5), 150 \mathrm{mM} \mathrm{NaCl}$ and $1 \%$ Triton X-100] after $24 \mathrm{hr}$. And the caspase-3 activity was detected using a kit from Beyotime Institute of Biotechnology according to the instruction by the manufacturer.

\section{Immunofluorescence}

Immunofluorescence staining was used to determine the induction of SP-C activity in AEC II treated with different concentrations of LPS, IKK-16 and PDTC treatment. At $24 \mathrm{hr}$ after treatment with different concentrations of LPS, IKK-16 and PDTC treatment, AEC II cells were fixed with $4 \%$ paraformaldehyde and permeabilized by $80 \%$ cold methanol. After washing with PBS, cover slips were then incubated in PBS with 3\% bovine serum albumin for $10 \mathrm{~min}$ at room temperature. Primary antibodies against the active form of caspase-3 (BD Systems Ltd., Abingdon, UK) and Tom 20 (Cell Signaling Technology,
Inc., Beverly, MA, USA) in PBS plus $0.1 \%$ Tween 20 were then added and incubated for $1 \mathrm{hr}$ at room temperature. After three washes with PBS, the cells were incubated with a fluorescence-conjugated secondary antibody in the dark for $1 \mathrm{hr}$. For nuclear staining, the cells were subsequently stained with $0.5 \mathrm{mg} / \mathrm{mL}$ DAPI dye (SigmaAldrich) for $5 \mathrm{~min}$ before examination under a fluorescence microscope. Images of mitochondria were collected using a Leica confocal microscope.

\section{Western blot analysis}

AEC II cells were seeded at a density of $2 \times 10^{6}$ cells in a $25 \mathrm{~cm}^{2}$ flask for $24 \mathrm{hr}$. After incubation, cells were pretreated with various doses of LPS, IKK-16 and PDTC for $12 \mathrm{hr}$. Cells were collected and lysed on ice, cell lysates were clarified via centrifugation and then the supernatants were collected and stored at $-70^{\circ} \mathrm{C}$ until use.

Protein concentrations were measured using the Bradford method. An equal amount of protein was loaded and separated using $10 \%$ polyacrylamide gel electrophoresis and transferred onto a polyvinylidene fluoride membrane. The nonspecific site was blocked with $5 \%$ nonfat dried milk in $50 \mathrm{mM}$ Tris-buffered saline containing $0.1 \%$ Tween-20 (TBST) for $1 \mathrm{hr}$ at room temperature, and then the membrane was incubated with the specific primary antibody $(1: 500)$ at $4^{\circ} \mathrm{C}$ overnight. Primary antibodies against IKK $\alpha, \operatorname{IKK} \beta, \operatorname{I\kappa B} \alpha, p$-I $\mathrm{KB} \alpha, \mathrm{NF}-\kappa \mathrm{B}$ p 50 , NF- $\kappa$ B p65, Caspase-3, and SP-C were purchased from Cell Signalling Technology. Following three washes with TBST, the blots were incubated with the secondary horseradish peroxidase-conjugated goat anti-rat IgG antibody (Beyotime Institute of Biotechnology) (1:1000) for $1 \mathrm{hr}$ at room temperature. Subsequently, the blots were washed again for three times with TBST and then visualized using an enhanced chemiluminescence (ECL) kit according to the manufacturer's instructions. The band densities were quantified from three different observations using ImageJ software (National Institutes of Health, Bethesda, MD, USA).

\section{Statistical analysis}

Results were expressed as means \pm standard deviations (SD) calculated from three independent experiments. A Student's t-test was used to compare the changes of all the measurable variables in this study. $P<0.05$ was considered a significant difference.

\section{RESULTS}

\section{Effects of different concentrations of LPS, IKK-16 and PDTC on AEC II cell growth}

To examine the biological effects of different concen- 
trations of LPS, AEC II cells were treated with varying doses of LPS $(0,20,40,80,160 \mu \mathrm{g} / \mathrm{mL})$ for 24,48 and $72 \mathrm{hr}$, and cell viability was assayed by MTT method. LPS decreased the cell viability with time and dose increasing (Fig. 1). Based on this, we used $80 \mu \mathrm{g} / \mathrm{mL}$ LPS in subsequent experiments. Later on, we determined $10 \mu \mathrm{M}$ IKK16 or PDTC in subsequent experiments in a trial treating cells with two concentrations of IKK-16 and PDTC ( 0 or $10 \mu \mathrm{M})$ for $20 \mathrm{~min}$ prior to LPS $(80 \mu \mathrm{g} / \mathrm{mL})$ exposure for 24, 48 and $72 \mathrm{hr}$, in which IKK-16 and PDTC decreased the decline of cell viability as a result of LPS insult (Fig. 1).

\section{Effect of LPS on apoptotic death of AEC II cells}

We also investigated whether LPS can induce the apoptosis of AEC II Cells. The ratio of cells with apoptotic nuclear morphology (fragmented nuclei and condensed chromatin) to total cells counted was significantly increased at $24 \mathrm{hr}$ post-treatment of LPS, comparing to that of only DMSO treatment (Fig. 2A). As depicted in Fig. 2B, LPS treatment resulted in a significant increase in the percentage of Annexin $\mathrm{V}$ positive cells in a dose-dependent manner. Data from the Annexin V assay was consistent with DAPI staining. Caspase-3 is a key effector in the process of apoptotic cell death. Fig. 2C showed that the expression of caspase- 3 was markedly

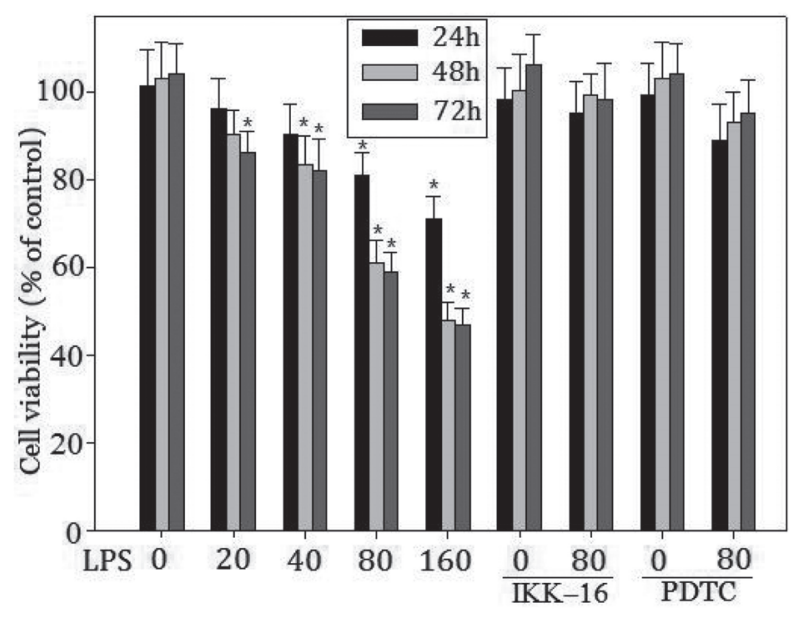

Fig. 1. Effects of lipopoplysaccharide (LPS) on viability of rat alveolar epithelial type II cells (AEC II). AEC II cells were exposed to $0,20,40,80,160 \mu \mathrm{g} / \mathrm{mL}$ LPS, $5 \mu \mathrm{M}$ PDTC, $5 \mu \mathrm{M}$ PDTC $+80 \mu \mathrm{g} / \mathrm{mL}$ LPS, $5 \mu \mathrm{M}$ IKK- 16 , $5 \mu \mathrm{M}$ IKK- $16+80 \mu \mathrm{g} / \mathrm{mL}$ LPS for 24,48 and $72 \mathrm{hr}$, respectively. Cell viability was analyzed using a colorimetric method. Each value represents mean \pm S.E.M. for $\mathrm{n}=5$. * values significantly differ from the respective control, $p<0.05$. increased in LPS-treated cells, as compared to controls. As shown in Fig. 2D, LPS significantly increased the expression of caspase- 3 in a concentration-dependent manner. Caspase-3 expression incubated with $80 \mu \mathrm{g} / \mathrm{mL}$ LPS for $24 \mathrm{hr}$ was $0.70 \pm 0.04$ while the negative control value was $0.29 \pm 0.01$ (Fig. 2D). Also, LPS demonstrated a dose-dependent increase in caspase- 3 activity by $6.17 \%$, $14.08 \%$ and $41.18 \%$ at the concentrations of 20,40 and $80 \mu \mathrm{g} / \mathrm{mL}$ in caspase- 3 activity assay as compared to the control (Fig. 2E).

\section{Effect of LPS on SP-C expression}

Western blotting analysis was carried out to determine the effects of LPS on SP-C protein production in AEC II cells. SP-C protein could be detected in untreated AEC II cells. Exposure of AEC II cells to 20, 40 and $80 \mu \mathrm{g} / \mathrm{mL}$ LPS decreased SP-C protein synthesis for $12 \mathrm{hr}$ (Fig. 3A). Treatment of AEC II cells with 20, 40 and $80 \mu \mathrm{g} / \mathrm{mL}$ LPS for $12 \mathrm{hr}$ caused significant 29.6, 42.9 and 54.4\% decreases in the levels of SP-C protein, respectively (Fig. 3B).

\section{LPS-induced AEC II cell apoptosis and surfactant protein-C expression inhibition is mediated by activation of NF-KB pathway}

$\mathrm{NF}-\kappa \mathrm{B}$ plays a central role in modulating sepsis and endotoxemia-induced increases in proinflammatory mediators and organ dysfunction (Abrahan, 2003). Since p50 and p65 are major components of NF- $\kappa \mathrm{B}$, which is activated by LPS in AEC II cells, we examined the expression of p50 and p65 by Western blotting. We found LPS treatment concentration-dependently increased p50 and p65 levels (Fig. 4A). When treated AEC II cells with 20, 40 and $80 \mu \mathrm{g} / \mathrm{mL}$ LPS for $12 \mathrm{hr}$, the levels of NF- $\kappa B$ p65 protein can cause significant $34.9,39.9$ and $40.8 \%$ increases, respectively (Fig. 4B). Meanwhile, the levels of NF- $\kappa$ B p50 protein increase 30.6, 44.1 and 71.0\%, respectively (Fig. 4B). NF- $\kappa \mathrm{B}$ is known to be activated when I $\kappa \mathrm{B}-\alpha$ phosphorylation are induced (Baeuerle and Baltimore, 1996). Here, we investigated whether the LPS can induce I $\mathrm{B}-\alpha$ degradation in AEC II cells with anti-I $\kappa$ B- $\alpha$ antibody by Western blotting. However, LPS induced I $\kappa \mathrm{B}-\alpha$ degradation was not detected in a concentration-dependent manner (Fig. 4A). We also examined the effect of LPS inducing I $\mathrm{B}-\alpha$ phosphorylation by Western blotting, and found that LPS induced I $\kappa \mathrm{B}-\alpha$ phosphorylation in a concentration-dependent manner (Fig. 4A). Treatment of AEC II cells with 20, 40 and $80 \mu \mathrm{g} / \mathrm{mL}$ LPS for $12 \mathrm{hr}$ caused significant 35.4, 72.1 and $74.2 \%$ increases in the levels of $p$-I $\kappa \mathrm{B} \alpha$ protein, respectively (Fig. 4B). IкBs are phosphorylated by IKKs (Matsubara et al., 2005). The expression patterns of IKK $\alpha$ 
Apoptosis and surfactant protein-C expression inhibition induced by lipopolysaccharide
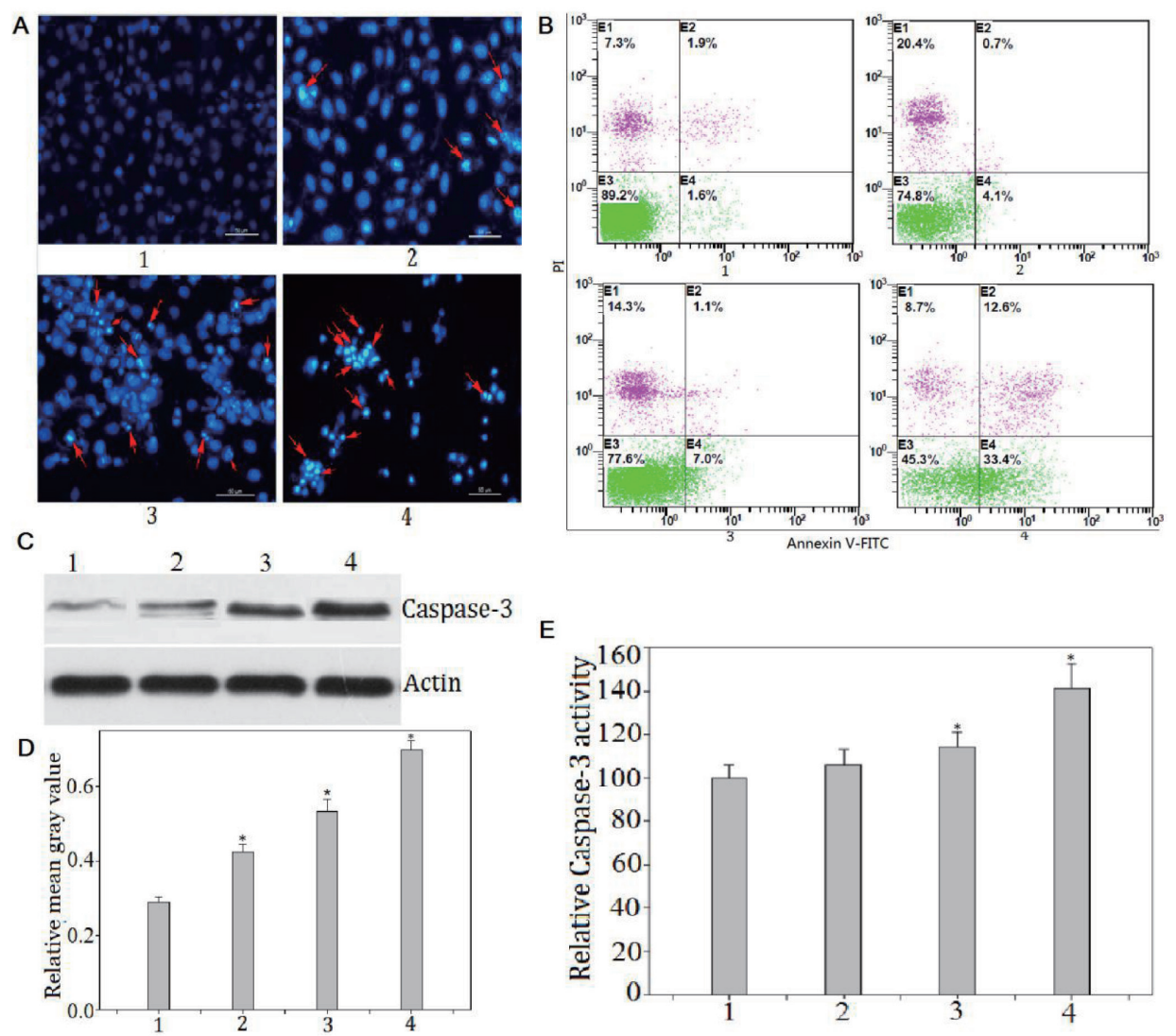

Fig. 2. Effects of LPS on the apoptosis of AEC II cells. (A) Nuclear morphology was analysed by fluorescence microscopy after DAPI staining of cells treated for $24 \mathrm{hr}$ with LPS (1:0 $\mu \mathrm{g} / \mathrm{mL}, 2: 20 \mu \mathrm{g} / \mathrm{mL}, 3: 40 \mu \mathrm{g} / \mathrm{mL}, 4: 80 \mu \mathrm{g} / \mathrm{mL})$, representative images are shown (Scale bar, $50 \mu \mathrm{m}$ ). (B) Apoptosis was analysed by annexin V/PI staining after $24 \mathrm{hr}$ of treatment with LPS at the indicated concentrations (1:0 $\mu \mathrm{g} / \mathrm{mL}, 2: 20 \mu \mathrm{g} / \mathrm{mL}, 3: 40 \mu \mathrm{g} / \mathrm{mL}, 4: 80 \mu \mathrm{g} / \mathrm{mL})$, representative histograms are shown. (C) Caspase-3 was detected by Western blotting after $24 \mathrm{hr}$ of treatment with LPS at the indicated concentrations $(1: 0 \mu \mathrm{g} /$ $\mathrm{mL}, 2: 20 \mu \mathrm{g} / \mathrm{mL}, 3: 40 \mu \mathrm{g} / \mathrm{mL}, 4: 80 \mu \mathrm{g} / \mathrm{mL}$ ). (D) The caspase-3 protein bands were quantified and statistically analyzed by ImageJ software. (E) The effect of LPS on caspase-3 activity was measured using the caspase-3 Assay Kit. Each value represents the mean \pm S.E.M. for $n=3$. The symbol $*$ indicates that a value significantly $(p<0.05)$ differed from the control groups.

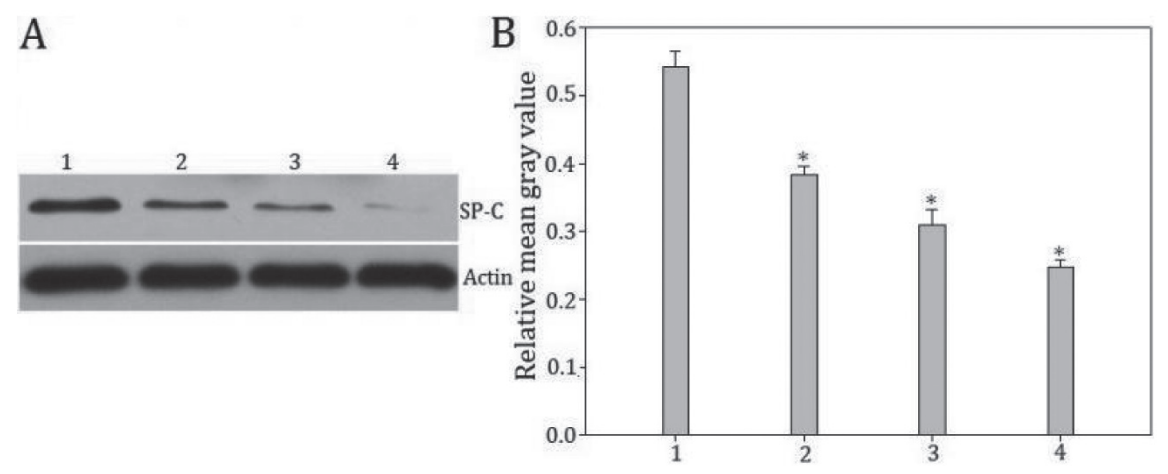

Fig. 3. Effects of LPS on SP-C expression in AEC II cells. (A) SP-C was detected by Western blotting after 24 hr of treatment with LPS at the indicated concentrations (1:0 $\mu \mathrm{g} / \mathrm{mL}, 2: 20 \mu \mathrm{g} / \mathrm{mL}, 3: 40 \mu \mathrm{g} / \mathrm{mL}, 4: 80 \mu \mathrm{g} / \mathrm{mL}$ ). (B) The SP-C protein bands were quantified and statistically analyzed by ImageJ software. Three independent experiments were performed; the data are presented as the mean \pm S.D. $\left({ }^{*} p<0.05\right)$. 
A

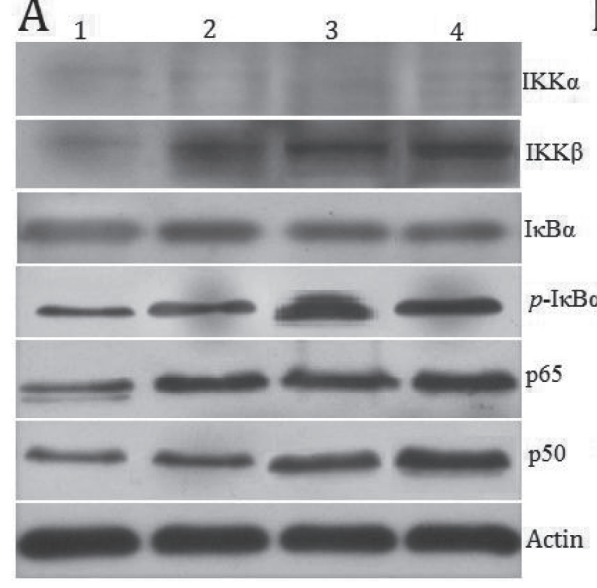

B

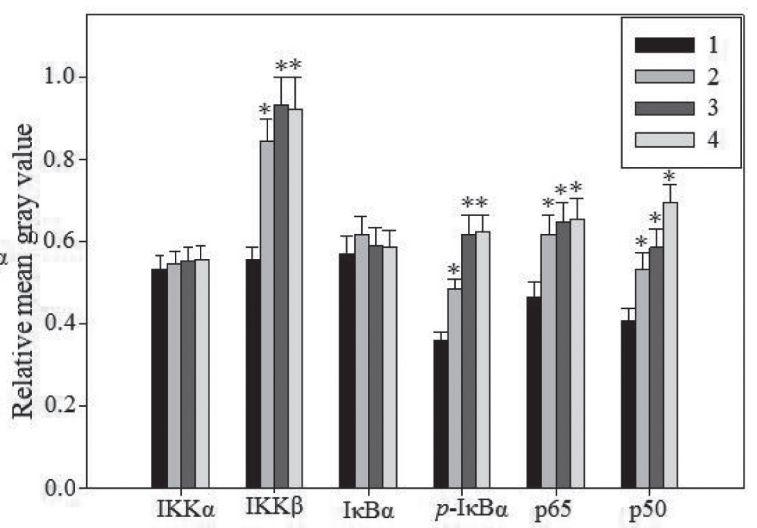

Fig. 4. Effects of LPS on the protein expression of NF- $\mathrm{\kappa B}$ pathway. (A) AEC II cells were treated with the indicated concentrations (1: $0 \mu \mathrm{g} / \mathrm{mL}, 2: 20 \mu \mathrm{g} / \mathrm{mL}, 3: 40 \mu \mathrm{g} / \mathrm{mL}, 4: 80 \mu \mathrm{g} / \mathrm{mL}$ ) of LPS for $24 \mathrm{hr}$. Total cellular proteins were prepared and Western

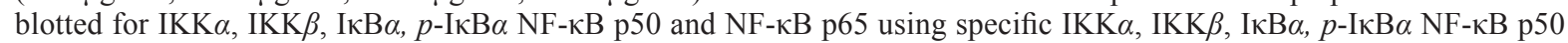
and NF- $\kappa \mathrm{B}$ p65 antibodies. $\beta$-Actin was used as an internal control. Experiments were repeated three times and similar results were obtained. (B) The bands of IKK $\alpha, \operatorname{IKK} \beta, \operatorname{I} \kappa \mathrm{B} \alpha, p-\mathrm{I} \kappa \mathrm{B} \alpha \mathrm{NF}-\kappa \mathrm{B} \mathrm{p} 50$ and NF- $\kappa \mathrm{B}$ p 65 proteins were quantified and statistically analyzed by ImageJ software. Three independent experiments were performed; the data are presented as the mean \pm S.D. (column, ${ }^{*} p<0.05$ ).

and $\operatorname{IKK} \beta$ proteins were evaluated with the concentrations $(20,40,80 \mu \mathrm{g} / \mathrm{mL})$ of LPS (Fig. 4A). Treatment of AEC II cells with 20, 40 and $80 \mu \mathrm{g} / \mathrm{mL}$ LPS for $12 \mathrm{hr}$ caused significant $51.8,67.8$ and $65.9 \%$ increases in the levels of IKK $\beta$ protein, respectively (Fig. 4B).

\section{LPS-induced apoptotic death of AEC II cells is mediated by IKK-16 and PDTC}

To determine the role of NF- $\kappa \mathrm{B}$ pathway in LPS-induced apoptosis, IKK-16 (a IKK inhibitor) and PDTC (a $\mathrm{NF}-\kappa \mathrm{B}$ inhibitor) were administered to inhibit the expression of IKK $\alpha$ and NF- $\kappa \mathrm{B}$. As shown in Figs. 5A and 5B, the cell apoptosis treated with only PDTC or IKK-16 did not show significant differences compared with that of non-treated cells, while IKK-16 and PDTC effectively attenuated LPS-induced cell apoptosis. Meanwhile, PDTC and IKK-16 further attenuated LPS-induced caspase-3 expression in AEC II cells (Figs. 5C and D). Overall, these data suggest that the activation of NF- $\kappa$ B pathway by LPS contributed to cell apoptosis in AEC II cells.

\section{LPS-inhibited SP-C expression of AEC II cells is mediated by IKK-16 and PDTC}

LPS at the concentration of $80 \mu \mathrm{g} / \mathrm{mL}$ can significantly decrease the expression of SP-C. Pretreatment of AEC II cells with PDTC or IKK-16 $(1$ and $5 \mu \mathrm{M})$ reversed the LPS decreased SP-C expression (Figs. 6A and B). More- over, results from immunofluorescence labeling for SP-C in AEC II cells with or without the inhibitor ( $5 \mu \mathrm{M}$ PDTC or IKK-16) pretreatment performed in parallel with previous results, which revealed that the expression of SP-C increased to some extent in cells pretreated with PDTC or IKK-16 compared to those without pretreatment, namely LPS-treated only (Fig. 6C).

\section{DISCUSSION}

Mortality remains high among patients with sepsis-associated acute respiratory distress syndrome (ARDS), in spite of improvements in supportive treatment of ARDS (Tsai et al., 2015). Sepsis-induced ARDS is characterized by lung epithelial and endothelial cell injury, neutrophil influx (Kitamura et al., 2001). The widespread destruction of alveolar epithelium, explained largely by apoptosis, contributes to the development of septic ARDS (Kitamura et al., 2001; Matthay and Wiener-Kronish, 1990; Wiener-Kronish et al., 1991). For example, epithelial type II cells showed a significant increase in apoptosis in animal models of LPS-induced acute lung injury (Kitamura et al., 2001). Given the growing body of evidence that epithelial cell apoptosis is known to be pivotal contributor to pathogenesis of sepsis-induced lung injury (Kutsukake et al., 2014; Imazu et al., 2011). At present study, LPS-induced primary cultured rat AEC II cell death 
Apoptosis and surfactant protein-C expression inhibition induced by lipopolysaccharide
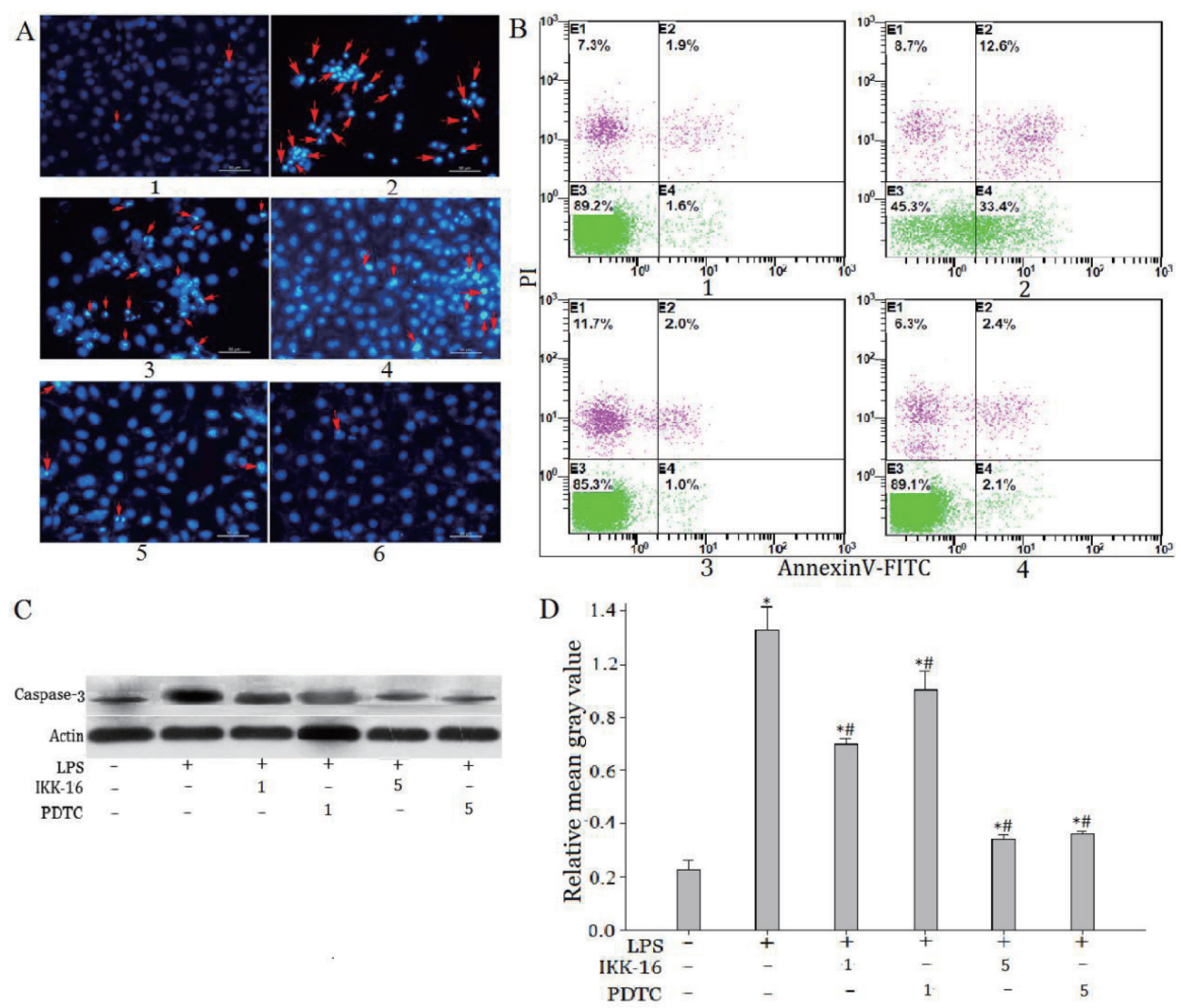

Fig. 5. IKK-16 (a IKK inhibitor) and PDTC (a NF- $\mathrm{kB}$ inhibitor) reversed LPS-induced AEC II cell apoptosis. (A) IKK-16, PDTC or control media were pretreated AEC II cells for $1 \mathrm{hr}$, and then the cells were treated with or without $80 \mu \mathrm{g} / \mathrm{mL}$ LPS for an additional $24 \mathrm{hr}$. Nuclear morphology was analysed by fluorescence microscopy after DAPI staining of cells (1: $0 \mu \mathrm{g} / \mathrm{mL}$ LPS, 2: $80 \mu \mathrm{g} / \mathrm{mL}$ LPS, 3: $80 \mu \mathrm{g} / \mathrm{mL}$ LPS + $1 \mu \mathrm{M}$ IKK-16, 4: $80 \mu \mathrm{g} / \mathrm{mL}$ LPS $+5 \mu \mathrm{M}$ IKK-16, 5: $80 \mu \mathrm{g} / \mathrm{mL}$ LPS + $1 \mu \mathrm{M}$ PDTC, 6: $80 \mu \mathrm{g} / \mathrm{mL}$ LPS $+5 \mu \mathrm{M}$ PDTC), representative images are shown (Scale bar, $50 \mu \mathrm{m}$ ). (B) AEC II cells were pretreated with $5 \mu \mathrm{M}$ IKK-16, $5 \mu \mathrm{M}$ PDTC or control media for $1 \mathrm{hr}$ and then treated with or without $80 \mu \mathrm{g} / \mathrm{mL}$ LPS for an additional $24 \mathrm{hr}$; the cell cycle distribution was analysed by flow cytometry (1:0 $0 \mathrm{~g} / \mathrm{mL}$ LPS, $2: 80 \mu \mathrm{g} / \mathrm{mL}$ LPS, 3: $80 \mu \mathrm{g} /$ $\mathrm{mL}$ LPS $+5 \mu \mathrm{M}$ IKK-16, 4: $80 \mu \mathrm{g} / \mathrm{mL}$ LPS $+5 \mu \mathrm{M}$ PDTC). The data from three independent experiments are presented as the mean \pm S.D. $(* p<0.05)$. (C) Cells were treated with or without $80 \mu \mathrm{g} / \mathrm{mL}$ LPS in the presence or absence of the indicated concentrations of IKK-16 or PDTC, and the expression of caspase-3 in AEC II cells was examined by Western blotting. (D) The bands of caspase-3 protein were quantified and statistically analyzed by ImageJ software. Three independent experiments were performed; the data are presented as the mean \pm 480 S.D. (column, ${ }^{*} p<0.05$ ).

was investigated. The current study showed that AEC II cells treated with LPS resulted in cell growth inhibition and apoptosis by detecting DNA condense, early/later stage apoptosis, caspase- 3 expression and caspase-3 activity.

AEC II cells serve important functions including synthesis and secretion of pulmonary surfactants (Wu et al., 2015). SP-C is one of the important pulmonary surfactants that can reduce the surface tension at the alveolar air liquid interface and provide alveolar stability necessary for normal ventilation (Mason et al., 2000). We found that the expression of SP-C was abnormally decreased in AEC
II cells after exposure to LPS, confirming the damage to the normal function of the lung.

$\mathrm{NF}-\kappa \mathrm{B}$ is a key transcriptional factor, which plays a critical role in the regulation of cell survival genes (Pan et al., 2014). NF- $\mathrm{KB}$ (a heterodimer of $\mathrm{p} 65$ and $\mathrm{p} 50$ ) is located in the cytoplasm as an inactive complex bound to I $\mathrm{B}-\alpha$, which is phosphorylated and subsequently degraded, then dissociates to produce activated NF- $\mathrm{kB}$ (Baeuerle and Baltimore, 1996). In present study, it was found that the expressions of NF- $\mathrm{kB}$ p 65 and $\mathrm{p} 50$ were induced by LPS in a concentration-dependent manner, 


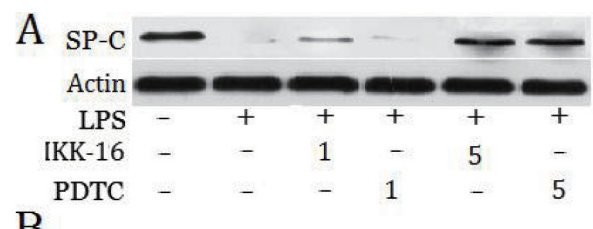

\section{C}

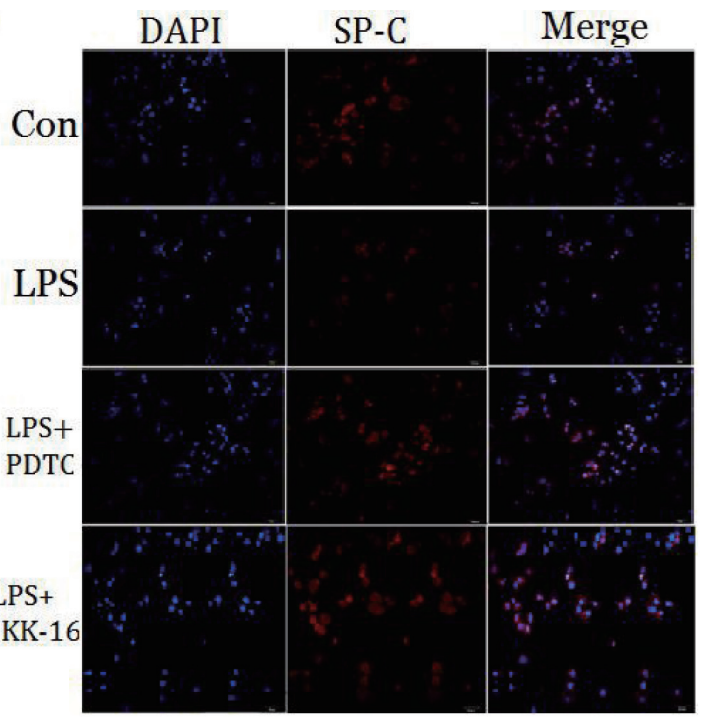

Fig. 6. IKK-16 and PDTC reversed the effects of LPS on SP-C expression in AEC II cells. (A) IKK-16, PDTC or control media were pretreated AEC II cells for $1 \mathrm{hr}$, and then the cells were treated with or without $80 \mu \mathrm{g} / \mathrm{mL}$ LPS for an additional $24 \mathrm{hr}$. SP-C expression was detected by Western blotting. (B) The SP-C protein bands were quantified and statistically analyzed by ImageJ software. Three independent experiments were performed; The data are presented as the mean \pm S.D. (column, ${ }^{*} p<0.05$ ). (C) Cells were treated with or without $80 \mu \mathrm{g} / \mathrm{mL}$ LPS in the presence or absence of $5 \mu \mathrm{M}$ IKK-16 or PDTC, and the expression of SP-C was detected by immunofluorescence staining. Scale bar, $50 \mathrm{~mm}$. Results are representative of three independent experiments.

and the phosphorylation of I $\kappa$ B- $\alpha$, which is required for p65 activation, were increased in cells treated with LPS. Moreover, the phosphorylation of I $\mathrm{B}-\alpha$ bound NF- $\kappa \mathrm{B}$ is considered to be mediated by IKK at two conserved serines in the N-terminal domain of I $\kappa$ B- $\alpha$ (Baeuerle and Baltimore, 1996). In our research, we found that the expression of IKK $\beta$ protein rather than IKK $\alpha$ was significantly increased when AEC II cells were treated with different concentrations of LPS. Meanwhile, NF- $\kappa \mathrm{B}$ inhibitor PDTC blocked NF- $\mathrm{NB}$ activity and IKK inhibitor IKK-16 suppressed IKK $\beta$ phosphorylation effectively attenuated LPS-induced cell apoptosis and reversed the LPS-decreased SP-C expression. Thus, we propose that LPS induced septic ARDS is partly attributed to LPS's ability to modulate alveolar epithelium cell apoptosis and decrease the expression of SP-C through regulating IKK/ $\mathrm{NF}-\kappa \mathrm{B}$ signal activation in the lung.

\section{ACKOWLEDGMENTS}

This research was supported by the Chinese National Natural Science Foundation (81503221), Guangdong Natural Science Foundation (2014A030310365), Traditional Chinese Medicine Administration of Guangdong
Province Funded Research Projects (20141149), China Postdoctoral Science Foundation (2015M570729), Shenzhen strategic emerging industry development special fund (CXZZ20150402104158 173), Science and Technology Project of Baoan District Shenzhen (2014040), and Science, Technology \& Innovation Commission of Shenzhen Municipality (JCYJ20140419122040615, JCYJ20140414111 244488).

Conflict of interest---- The authors declare that there is no conflict of interest.

\section{REFERENCES}

Abrahan, E. (2003): Nuclear factor- $\kappa B$ and its role in sepsis-associated organ failure. J. Infect. Dis., 187 (Suppl 2), S364-369.

Almlén, A., Stichtenoth, G., Linderholm, B., HaegerstrandBjörkman, M., Robertson, B., Johansson, J. and Curstedt, T. (2008): Surfactant proteins B and C are both necessary for alveolar stability at end expiration in premature rabbits with respiratory distress syndrome. J. Appl. Physiol., 104, 1101-1108.

Avery, M.E. (2000): Surfactant deficiency in hyaline membrane disease: the story of discovery. Am. J. Respir. Crit. Care Med., 161, 1074-1075.

Baeuerle, P.A. and Baltimore, D. (1996): NF- $\kappa B$ : ten years after. Cell, 87, 13-20. 
Apoptosis and surfactant protein-C expression inhibition induced by lipopolysaccharide

Cazzola, M., Page, C.P. and Matera, M.G. (2004): Alternative and/ or integrative therapies for pneumonia under development. Curr. Opin. Pulm. Med., 10, 204-210.

Chuang, C.Y., Chen, T.L., Cherng, Y.G., Tai, Y.T., Chen, T.G. and Chen, R.M. (2011): Lipopolysaccharide induces apoptotic insults to human alveolar epithelial A549 cells through reactive oxygen species-mediated activation of an intrinsic mitochondrion-dependent pathway. Arch. Toxicol., 85, 209-218.

Clements, J.A. and King, R.J. (1976): The Biochemical Basis of Pulmonary Function. Dekker, New York. 363-387.

Cruz, A., Worthman, L.A., Serrano, A.G., Casals, C., Keough, K.M. and Pérez-Gil, J. (2000): Microstructure and dynamic surface properties of surfactant protein SP-B/dipalmitoylphosphatidylcholine interfacial films spread from lipid-protein bilayers. Eur. Biophys. J., 29, 204-213.

Danlois, F., Zaltash, S., Johansson, J., Robertson, B., Haagsman, H.P., van Eijk, M., Beers, M.F., Rollin, F., Ruysschaert, J.M. and Vandenbussche, G. (2000): Very low surfactant protein C contents in newborn Belgian White and Blue calves with respiratory distress syndrome. Biochem. J., 351, 779-787.

Gill, S.E., Rohan, M. and Mehta, S. (2015): Role of pulmonary microvascular endothelial cell apoptosis in murine sepsis-induced lung injury in vivo. Respir. Res., 16, 109.

Glasser, S.W., Burhans, M.S., Korfhagen, T.R., Na, C.L., Sly, P.D., Ross, G.F., Ikegami, M. and Whitsett, J.A. (2001): Altered stability of pulmonary surfactant in SP-C-deficient mice. Proc. Natl. Acad. Sci. USA, 98, 6366-6371.

Glasser, S.W., Senft, A.P., Whitsett, J.A., Maxfield, M.D., Ross, G.F., Richardson, T.R., Prows, D.R., Xu, Y. and Korfhagen, T.R. (2008): Macrophage dysfunction and susceptibility to pulmonary Pseudomonas aeruginosa infection in surfactant protein C-deficient mice. J. Immunol., 181, 621-628.

Hu, Z.X., Gao, M., Zhao, J.N., Shi, Y., Wang, L., Song, H.P., Li, R. and Zeng, C.Y. (2012): Glycochenodeoxycholate induces rat alveolar epithelial type II cell death and inhibits surfactant secretion in vitro. Free Radic. Biol. Med., 53, 122-128.

Imazu, Y., Yanagi, S., Miyoshi, K., Tsubouchi, H., Yamashita, S., Matsumoto, N., Ashitani, J., Kangawa, K. and Nakazato, M. (2011): Ghrelin ameliorates bleomycin-induced acute lung injury by protecting alveolar epithelial cells and suppressing lung inflammation. Eur. J. Pharmacol., 672, 153-158.

Lawson, W.E., Polosukhin, V.V., Stathopoulos, G.T., Zoia, O., Han, W., Lane, K.B., Li, B., Donnelly, E.F., Holburn, G.E., Lewis, K.G., Collins, R.D., Hull, W.M., Glasser, S.W., Whitsett, J.A. and Blackwell, T.S. (2005): Increased and prolonged pulmonary fibrosis in surfactant protein C-deficient mice following intratracheal bleomycin. Am. J. Pathol., 167, 1267-1277.

Lukovic, D., Cruz, A., Gonzalez-Horta, A., Almlen, A., Curstedt, T., Mingarro, I. and Pérez-Gil, J. (2012): Interfacial behavior of recombinant forms of human pulmonary surfactant protein SP-C. Langmuir., 28, 7811-7825.

Kitamura, Y., Hashimoto, S., Mizuta, N., Kobayashi, A., Kooguchi, K., Fujiwara, I. and Nakajima, H. (2001): Fas/FasL-dependent apoptosis of alveolar cells after lipopolysaccharide-induced lung injury in mice. Am. J. Respir. Crit. Care Med., 163, 762-769.
Kutsukake, M., Matsutani, T., Tamura, K., Matsuda, A., Kobayashi, M., Tachikawa, E. and Uchida, E. (2014): Pioglitazone attenuates lung injury by modulating adipose inflammation. J. Surg. Res., 189, 295-303.

Mason, R.J., Kalina, M., Nielsen, L.D., Malkinson, A.M. and Shannon, J.M. (2000): Surfactant protein C expression in urethane-induced murine pulmonary tumors. Am. J. Pathol., 156, $175-182$.

Matsubara, M., Tamura, T., Ohmori, K. and Hasegawa, K. (2005): Histamine $\mathrm{H} 1$ receptor antagonist blocks histamine-induced proinflammatory cytokine production through inhibition of $\mathrm{Ca} 2+$-dependent protein kinase $\mathrm{C}, \mathrm{Raf} / \mathrm{MEK} / \mathrm{ERK}$ and IKK/

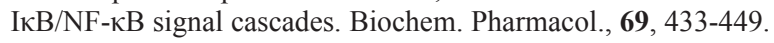

Matthay, M.A. and Wiener-Kronish, J.P. (1990): Intact epithelial barrier function is critical for the resolution of alveolar edema in humans. Am. Rev. Respir. Dis., 142, 1250-1257.

Nkadi, P.O., Merritt, T.A. and Pillers, D.A. (2009): An overview of pulmonary surfactant in the neonate: genetics, metabolism, and the role of surfactant in health and disease. Mol. Genet. Metab., 97, 95-101.

Pan, L.C., Xu, X.H., Zhang, N.N., Liu, N., Wu, D.L., Wang, Y., Peng, Q.S., Vandenplas, M., Wang, H.B. and Sun, W.C. (2014): HJB-1, a 17-hydroxy-jolkinolide B derivative, inhibits LPS-induced inflammation in mouse peritoneal macrophages. Int. Immunopharmacol., 21, 474-480.

Raetz, C.R., Ulevitch, R.J., Wright, S.D., Sibley, C.H., Ding, A. and Nathan, C.F. (1991): Gram-negative endotoxin: an extraordinary lipid with profound effects on eukaryotic signal transduction. FASEB J., 5, 2652-2660.

Rooney, S.A. (2001): Regulation of surfactant secretion. Comp. Biochem. Physiol. A Mol. Integr. Physiol., 129, 233-243.

Serrano, A.G. and Perez-Gil, J. (2006): Protein-lipid interactions and surface activity in the pulmonary surfactant system. Chem. Phys. Lipids., 141, 105-118.

Tsai, Y.F., Yu, H.P., Chang, W.Y., Liu, F.C., Huang, Z.C. and Hwang, T.L. (2015): Sirtinol inhibits neutrophil elastase activity and attenuates lipopolysaccharide-mediated acute lung injury in mice. Sci. Rep., 5, 8347.

Wang, Z., Gurel, O., Baatz, J.E. and Notter, R.H. (1996): Differential activity and lack of synergy of lung surfactant proteins SP-B and SP-C in interactions with phospholipids. J. Lipid Res., 37, $1749-1760$

Wiener-Kronish, J.P., Albertine, K.H. and Matthay, M.A. (1991): Differential responses of the endothelial and epithelial barriers of the lung in sheep to Escherichia coli endotoxin. J. Clin. Invest., 88, 864-875.

Wu, Y., Ma, J.Y., Woods, P.S., Chesarino, N.M., Liu, C., Lee, L.J., Nana-Sinkam, S.P. and Davis, I.C. (2015): Selective targeting of alveolar type II respiratory epithelial cells by anti-surfactant protein-C antibody-conjugated lipoplexes. J. Control. Release, 203, 140-149.

Yin, X.J., Li, L.H., Fan, H.X., Qu, W.W., Xie, L. and Feng, Z.C. (2012): Correlation between surfactant protein B mRNA expression and neonatal respiratory distress syndrome. Exp. Ther. Med., 4, 815-819. 